\section{Economically Optimal Plant Density for Machine-harvested Edamame}

\author{
Daljeet S. Dhaliwal \\ Department of Crop Sciences, University of Illinois, Urbana, IL 61801
}

\author{
Martin M. Williams II \\ Global Change and Photosynthesis Research Unit, USDA-ARS, Urbana, IL \\ 61801
}

Additional index words. economic analysis, Glycine max, Oxbo BH100 harvester, seeding rate

\begin{abstract}
Consumer demand for edamame [Glycine max (L.) Merr.], the vegetable version of soybean (Glycine max), has grown during the past decade in North America. Domestic production of edamame is on the rise; however, research to guide fundamental crop production practices, including knowledge useful for developing appropriate recommendations for crop seeding rate, is lacking. Field experiments near Urbana, IL, were used to quantify edamame response to plant density and determine the economically optimal plant density (EOPD) of machine-harvested edamame. Crop growth and yield responses to a range of plant densities $(24,700$ to 395,100 plants/ha) were quantified in four edamame cultivars (AGS 292, BeSweet 292, Gardensoy 42, and Midori Giant) across 2 years. Plots were harvested with the Oxbo BH100, a fresh market bean harvester. In general, as plant density increased, branch number and the ratio of pod mass to vegetative mass decreased, while plant height and leaf area index increased. Recovery, the percent of marketable pods in the machine-harvested sample, varied among cultivars from $86 \%$ to $95 \%$. Results identified the EOPD for machine-harvested edamame ranged from 87,000 to 120,000 plants/ha. When considering the effect of plant density on plant morphology, as well as seeding cost, harvester efficiency, recovery, and marketable pod yield, edamame EOPDs are considerably lower than seeding rates of up to 344,200 seeds/ha recommended in recent publications.
\end{abstract}

Edamame, an edible version of soybean (Glycine max), is emerging in popularity in North America. A nutritious and appetizing vegetable with a sweet, nutty flavor (Miles et al., 2000), edamame is harvested when pods are bright green and immature seeds are at their maximum size (Shanmugasundaram et al., 1991). The protein-rich seed is attractive to health-conscious consumers (Rao et al., 2002). Edamame seed also contains cholesterol-free fat (5.7\%), phosphorus (158 mg per $100 \mathrm{~g}$ ), calcium (78 mg per $100 \mathrm{~g})$, vitamin B1 $(0.4 \mathrm{mg}$ per 100 $\mathrm{g})$, vitamin B2 (0.17 mg per $100 \mathrm{~g})$, isoflavones and tocopherols (Shanmugamsundaram and Yan, 2004).

The United States is second in global graintype soybean production, accounting for 122.5

Received for publication 18 Oct. 2019. Accepted for publication 11 Dec. 2019.

Published online 6 February 2020.

Any opinions, findings, conclusions, or recommendations expressed in this publication are those of the author(s) and do not necessarily reflect the view of the U.S. Department of Agriculture (USDA). Mention of trade names or commercial products in this publication is solely for the purpose of providing specific information and does not imply recommendation or endorsement by the USDA. The USDA is an equal opportunity provider and employer.

M.M.W. is the corresponding author. E-mail: martin. williams@ars.usda.gov.

This is an open access article distributed under the CC BY-NC-ND license (https://creativecommons. org/licenses/by-nc-nd/4.0/). sity." Selecting the appropriate plant density is an important crop management decision in commercial edamame production where plant architecture determines efficiency of mechanical harvest (Zandonadi et al., 2010). Studies on grain-type soybean report that plant density influences plant height (Matsuo et al., 2018; Mehmet, 2008), number of main stem branches (Agudamu and Shiraiwa, 2016; Board and Kahlon, 2013), and plant biomass (Matsuo et al., 2018). Companies selling edamame seed identify seeding rates ranging from 197,600 plants/ha (Wannamaker Seeds, Saluda, NC) to 344,200 plants/ha (Johnny's Selected Seeds, Winslow, ME), which is similar to recommendations for grain-type soybean (Nafziger, 2009). However, peer-reviewed literature to develop such recommendations appears to be nonexistent. In addition, edamame seed is more expensive, ranging from $\$ 25$ to $\$ 50$ per $\mathrm{kg}$ for edamame (Fedco Seeds, Clinton, ME; Johnny's Selected Seeds, Winslow, ME; Wannamaker Seeds, Saluda, NC) compared with $\$ 2.5$ per kg for conventional grain soybean. Conventional grain soybean cost (per kilogram) were calculated based on grain soybean cost of $\$ 57.40$ per acre (USDA-ERS, 2019) and seeding rate assumed $22.68 \mathrm{~kg}$ (50 lbs) per acre.

The vegetable industry would benefit from research-based information on edamame response to plant density, including horticultural performance and an economic analysis. We define the EOPD as the plant density that maximizes grower profits when accounting for seed cost. The objectives of this study were to a) evaluate edamame plant morphology and yield response to plant density and b) determine the EOPD of machine-harvested edamame.

\section{Materials and Methods}

Germplasm selection and seed treatment. Edamame cultivars were selected based on availability of seed grown commercially in the United States. Four edamame cultivars used in the study were 'AGS 292' (Washington State University, Pullman, WA), 'Besweet 292' (Rupp Seeds, Wauseon, OH), 'Gardensoy 42' (University of Illinois, Urbana, IL), and 'Midori Giant' (Wannamaker Seeds, Saluda, NC). Before planting, edamame seeds were treated with mefenoxam (3.37 g per $100 \mathrm{~kg}$ seed) and fludioxonil $(2.27 \mathrm{~g}$ per $100 \mathrm{~kg}$ seed; Apron Maxx, Syngenta Crop Protection, Greensboro, NC) to prevent losses from soil pathogens.

Site characterization. Field experiments were conducted in 2017 and 2018 at University of Illinois Vegetable Crop Farm near Urbana, IL (lat. $40.08^{\circ} \mathrm{N}$, long. $88.26^{\circ} \mathrm{W}$ ). Each year of the experiment followed the grain-type soybean phase of a sweet corn-soybean rotation. The soil was a Flanagan silt loam (fine, smectitic, mesic Aquic Argiudolls). Before planting, fields were prepared using two passes of a field cultivator. Experiments were planted on 7 June 2017 and 23 May 2018, using a four-row cone planter (ALMACO, Nevada, IA).

Experimental approach. The experimental design was a randomized complete block with four replicates and treatments assigned in a split plot arrangement. The four cultivars were 


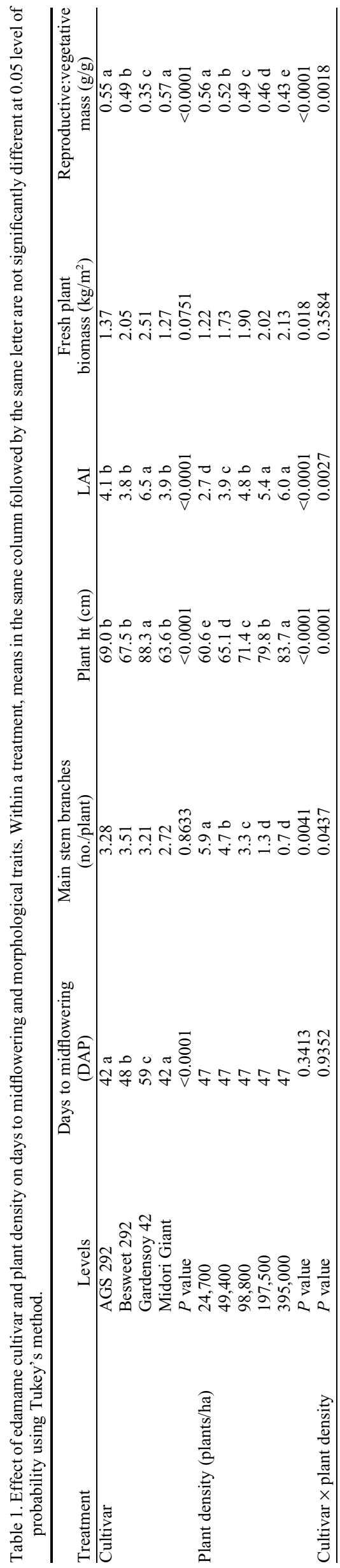

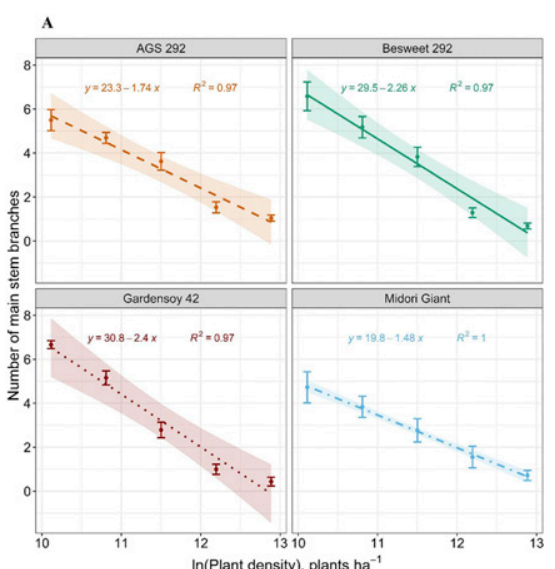
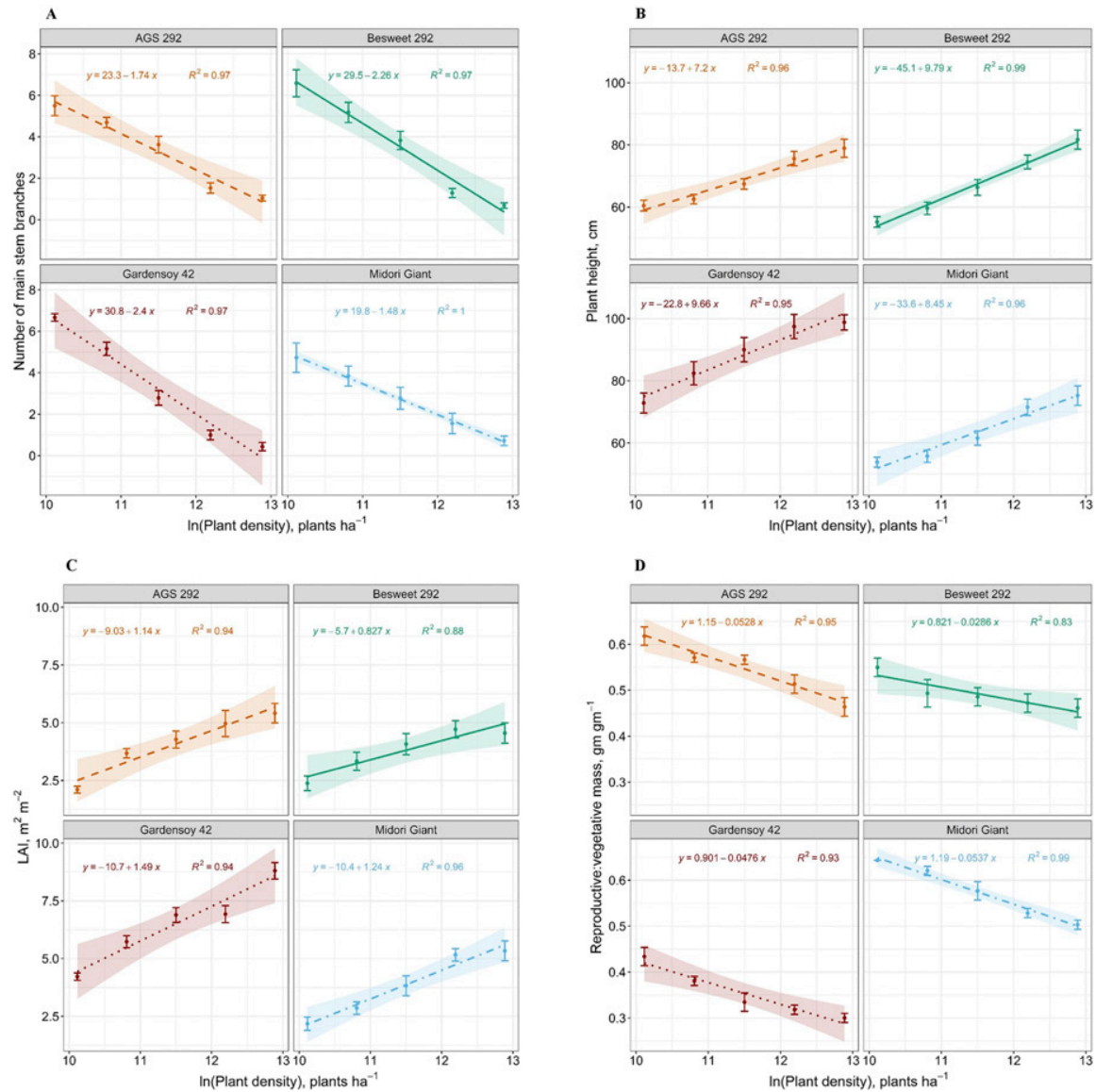

Fig. 1. Effect of edamame cultivar and plant density on (A) main stem branches, (B) plant height, (C) leaf area index, and (D) reproductive: vegetative mass. Simple linear regression models described the relationships. Ninety-five percent confidence intervals are shown by the shaded regions around the line of best fit.

assigned to main plots measuring 53 by $3 \mathrm{~m}$ (four rows spaced $76 \mathrm{~cm}$ ). Main plots were separated by a $3 \mathrm{~m}$ alley. Five target plant densities $(24,700,49,400,98,800,197,500$, and 395,000 plants/ha) were assigned to subplots measuring 9.1 by $3 \mathrm{~m}$. Subplots within each main plot were separated by a $1.5-\mathrm{m}$-wide alley. Plant densities were established by overseeding $30 \%$ at planting, then after emergence, hand thinning to appropriate target plant densities. $S$-metolachlor (Dual Magnum, Syngenta Crop Protection) was applied preemergence at a rate of $1780 \mathrm{~g}$ a.i./ha for weed control. Escaped weeds were removed with a single interrow cultivation at R1 crop growth stage (Fehr et al., 1971) and hand weeding, as needed. Experimental sites were irrigated using a linear irrigation system when rainfall was abnormally low.

Data collection. All data were collected on the center two rows of each subplot. Starting at floral bud initiation, the number of plants with at least a single flower were counted until at least $50 \%$ of plants from a sample of 10 continuous plants in each row began flowering (R1). Days to midflowering from planting date were recorded as days after planting (DAP) for each subplot. Once midflowering was reached, the following growth data were obtained. On the basis of five plants per plot, the total number of branches emerging from the main stem was counted, and plant height from soil surface to the apical meristem was measured. In addition, leaf area index (LAI) was measured in full sun within $2 \mathrm{~h}$ of solar noon with a linear ceptometer (AccuPAR Linear Ceptometer; Decagon Devices, Pullman, WA) by placing it parallel to and between the center two rows.

The Oxbo Pixall BH100 bean harvester was used to harvest pods of each cultivar at the full seed (R6) growth stage (Fehr et al., 1971). The entire length of the center two rows of each subplot were mechanically harvested and weighed (hereafter called "machine-harvest pod yield"). A 1-kg subsample of machineharvest pod yield was collected for each harvested row, and market-quality pods were retained and weighed (hereafter called "marketable pod yield"). Discolored, shriveled, unfilled, or mechanically damaged pods were not considered market-quality. Recovery (\%) was calculated as the ratio of marketable pod yield to machine-harvest pod yield.

Subplots also were subsampled for yield by hand. Over a 1-m length of both outside rows, plants were clipped at the soil surface and counted. Fresh plant biomass, including pods, was recorded. All marketable pods were removed and weighed (hereafter called "handharvested pod yield"). Pod yield per plant was calculated. "Reproductive:vegetative mass" was calculated as the ratio of hand-harvested pod yield to fresh plant biomass.

A ratio of machine-harvest pod yield to hand-harvested pod yield (interpolated to 


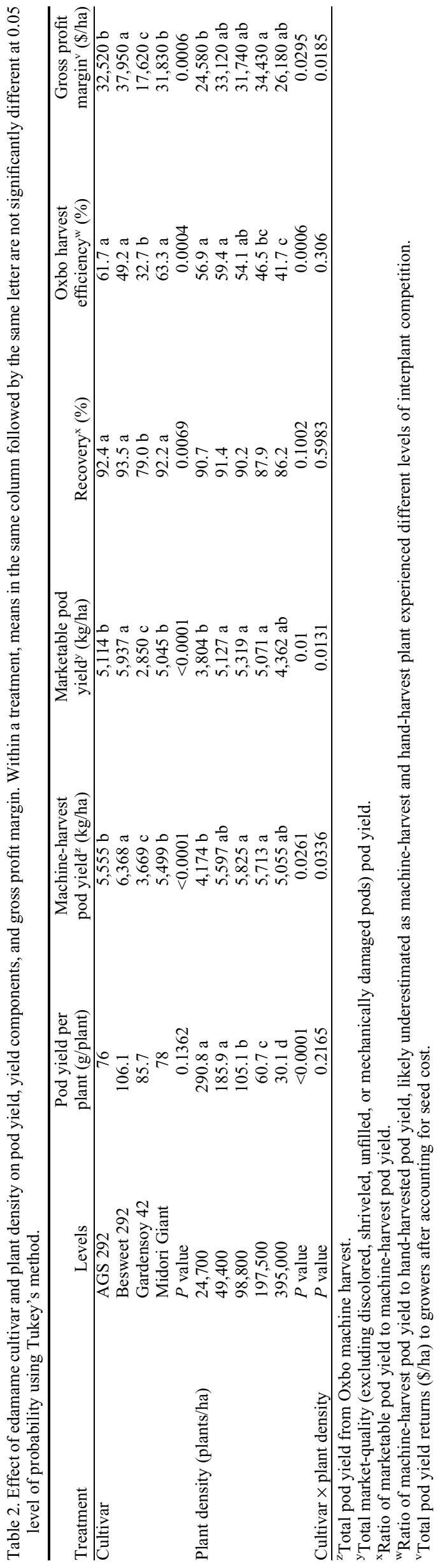

same scale of area) was calculated (hereafter called "Oxbo harvest efficiency"). Oxbo harvest efficiency is likely underestimated in the study because hand-harvested pod yield was recorded on plants in the border rows, where plants experienced less competition than in the center two rows.

Economic analysis. A partial budget economic analysis was conducted to determine the most profitable plant density for each cultivar. Edamame seed cost is highly variable; from $\$ 25$ per $\mathrm{kg}$ (Wannamaker Seeds, 2019), to $\$ 40$ per kg (Johnny's Selected Seeds, 2019), and $\$ 50$ per kg (Fedco Seeds, 2019). In this study, the preceding prices were averaged ( $\$ 38$ per $\mathrm{kg}$ ) to determine edamame seed cost, which was adjusted by 100 -seed mass for each cultivar. Therefore, seed costs were $\$ 9.0$ (AGS 292, Besweet 292, Gardensoy 42) and $\$ 10.8$ (Midori Giant) per 1000 seed. Wholesale price of marketable pods was assumed $\$ 6.6$ per $\mathrm{kg}$ for all cultivars. Seeding cost was calculated as the product of plant density (1000 plants per ha) and seed cost (\$ per 1000 seed). Yield return $(\$ / \mathrm{ha})$ was calculated as the product of marketable pod yield $(\mathrm{kg} / \mathrm{ha})$ and wholesale pod price $(\$ / \mathrm{kg})$. Finally, gross profit margin was calculated as the difference between yield return and seeding cost.

Statistical analyses. All response variables were analyzed with an analysis of variance (ANOVA) model using the mixed procedure in SAS (version 9.4, SAS Institute Inc., Cary, NC). The Shapiro-Wilk test of normality and Brown-Forsythe test for homogeneity of variance were performed on ANOVA residuals to test model assumptions. As needed, the BoxCox procedure was used to transform response variables to satisfy model assumptions. Edamame cultivar, target plant density, and their interactions were considered fixed effects. Year and replicates nested within year were treated as random effects. Mean comparisons for significant treatment effects were performed using Tukey's mean separation test $(\alpha=0.05)$.

Regression analyses were used to quantify the effect of plant density on response variables with significant plant density effects or cultivarby-plant density interactions. Response variables were fitted to linear or quadratic models as a function of plant density using leastsquares regression. The peak of marketable pod yield and gross profit margin regression models were identified to determine yieldoptimized plant density (YOPD) and EOPD for each cultivar. Nonoverlapping $95 \%$ confidence intervals were used to detect significant differences among cultivars for maximum marketable pod yield and maximum gross profit margin. Significant associations among response variables were quantified using Pearson's correlation coefficients at $\alpha=0.05$.

\section{Results}

Environmental conditions. Growing season conditions were favorable for edamame during experimental trial years. Mean air temperature for growing season was 23.1 and $23.7^{\circ} \mathrm{C}$ for 2017 and 2018 , respectively. Mean air temperature did not record any significant 
A

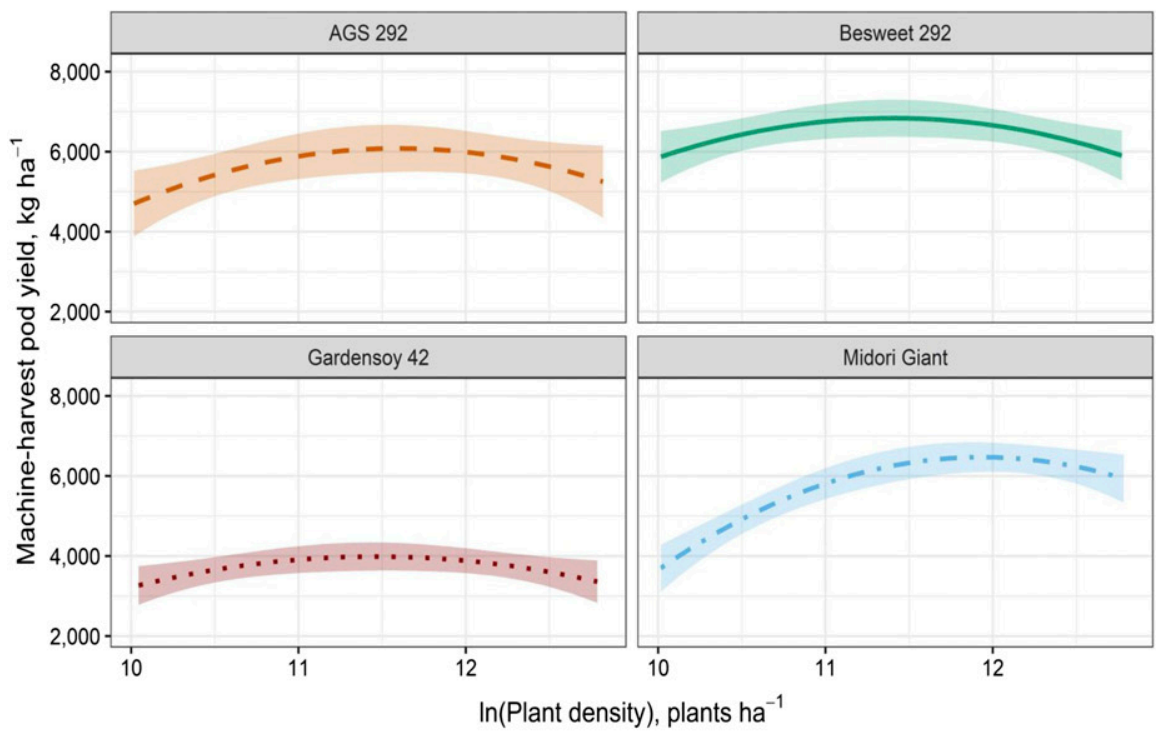

B

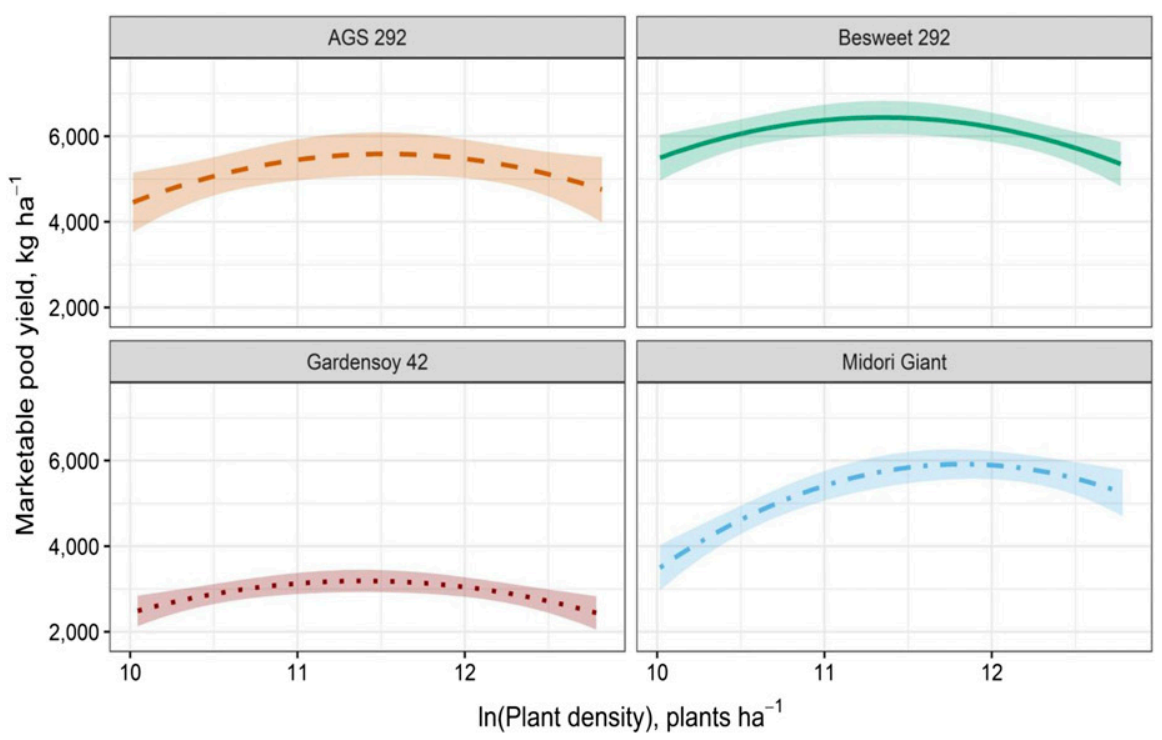

Fig. 2. Effect of edamame cultivar and plant density on (A) machine-harvest pod yield, and (B) marketable pod yield. Machine-harvest pod yield is the total pod yield from Oxbo machine harvest, and marketable pod yield is the total market-quality (excluding discolored, shriveled, unfilled, or mechanically damaged pods) pod yield. Quadratic regression models described the relationships. Ninety-five percent confidence intervals are shown by the shaded regions around the line of best fit.

departures from 30-year average (19812010). Total rainfall received during the growing season deviated from the 30 -year average $(32.9 \mathrm{~cm})$ for both $2017(18 \mathrm{~cm})$ and $2018(40$ $\mathrm{cm})$. However, supplemental sprinkler irrigation offset any water stress due to rainfall shortages in 2017 , and there were no extreme weather events reported during the growing season for either year (Illinois Climate Network, 2019).

Days to midflowering. Edamame cultivars differed in days to midflowering. 'AGS 292' and 'Midori Giant' flowered in $42 \mathrm{~d}$, compared with 'Gardensoy 42', which flowered in $59 \mathrm{~d}$ (Table 1).
Number of main stem branches. Although branching response to plant density differed among cultivars $(P=0.04)$, on average there was an 8-fold decline in main stem branches when comparing the lowest to highest plant density treatments (Fig. 1A, Table 1).

Plant height. There was an interactive effect of cultivar and plant density on plant height (Table 1). 'Gardensoy 42' had the tallest plants among all cultivars, averaging $88.3 \mathrm{~cm}$, while 'Midori Giant' produced the shortest plant, with an average height of 63.6 $\mathrm{cm}$ (Table 1). Nonetheless, plant height increased linearly with plant density for all cultivars (Fig. 1B).
LAI. Edamame cultivars showed different LAI responses to plant density. Overall, 'Gardensoy 42' produced the most dense canopy with an LAI average of 6.5, whereas 'Besweet 292' produced the least dense canopy, averaging an LAI of 3.8 (Table 1). Moreover, 'Gardensoy 42' had the steepest positive slope (1.49) for LAI across plant density, indicating the most rapid canopy closure among cultivars (Fig. 1C).

Fresh plant biomass. Plant density had a significant effect on fresh plant biomass $\left(\mathrm{kg} / \mathrm{m}^{2}\right)$ at harvest (Table 1). Also, the reproductive:vegetative mass ratio, a proxy for harvest index, varied across both cultivar and plant density. While the reproductive:vegetative mass ratio declined linearly with increasing plant density, the rate of decline was higher for 'AGS 292' and 'Midori Giant' compared with the other cultivars (Fig. 1D). A general decline in the ratio indicates plants shifted carbon allocation to leaves and stems in response to crowding stress.

Pod yield per plant. Pod yield per plant declined from $185.9 \mathrm{~g} / \mathrm{plant}$ at the lowest plant density, to $30.1 \mathrm{~g} /$ plant at the highest plant density (Table 2). Additionally, there was a positive relationship between number of main stem branches and pod yield per plant $(r=0.75)$.

Oxbo harvest efficiency and recovery. Oxbo harvest efficiency was significantly affected by both cultivar and plant density. Oxbo harvest efficiency decreased by $26.7 \%$ with plant density increasing from 24,700 to 395,000 plants/ha (Table 2). In addition, 'Gardensoy 42' had a poor Oxbo harvest efficiency $(32.7 \%)$ compared with the other three cultivars $(49.2 \%$ to $63.3 \%)$.

Like Oxbo harvest efficiency, 'Gardensoy 42' also had the lowest recovery among cultivars (Table 2). Both response variables showed a negative correlation with plant height ( $r=-0.59$ to -0.65$)$.

Machine-harvest pod yield, marketable pod yield, and YOPD. Edamame cultivar and plant density showed significant main effects as well as an interactive effect on machineharvest pod yield and marketable pod yield $(P<0.034)$. In general, the lowest yielding cultivar (Gardensoy 42 ) was $48 \%$ to $58 \%$ of the highest yielding cultivar (Besweet 292).

Quadratic regression models were fit to quantify yield responses to actual plant density for all cultivars (Fig. 2). The predicted maximum marketable pod yield and corresponding plant density were identified for each cultivar from quadratic model fit. The YOPD was the plant density corresponding to maximum predicted marketable pod yield. The YOPD for 'Besweet 292', 'Gardensoy 42', 'AGS 292', and 'Midori Giant' were identified as 90,000 plants/ha, 94,000 plants/ha, 106,000 plants/ha, and 137,000 plants/ha, respectively (Fig. 2B).

Gross profit margins and EOPD. Much like yield, there was significant main effect of cultivar and plant density as well as an interactive effect on gross profit margin $(P=0.018)$. On the basis of the quadratic regression model for each cultivar, maximum predicted gross profit margin and corresponding plant density (i.e., the EOPD) were identified (Fig. 3). Maximum gross profit margin of 'AGS 292', 'Besweet 292', and 'Midori Giant' were $\approx 2$-fold 
- AGS 292 - Besweet 292 * Gardensoy 42 * - Midori Giant

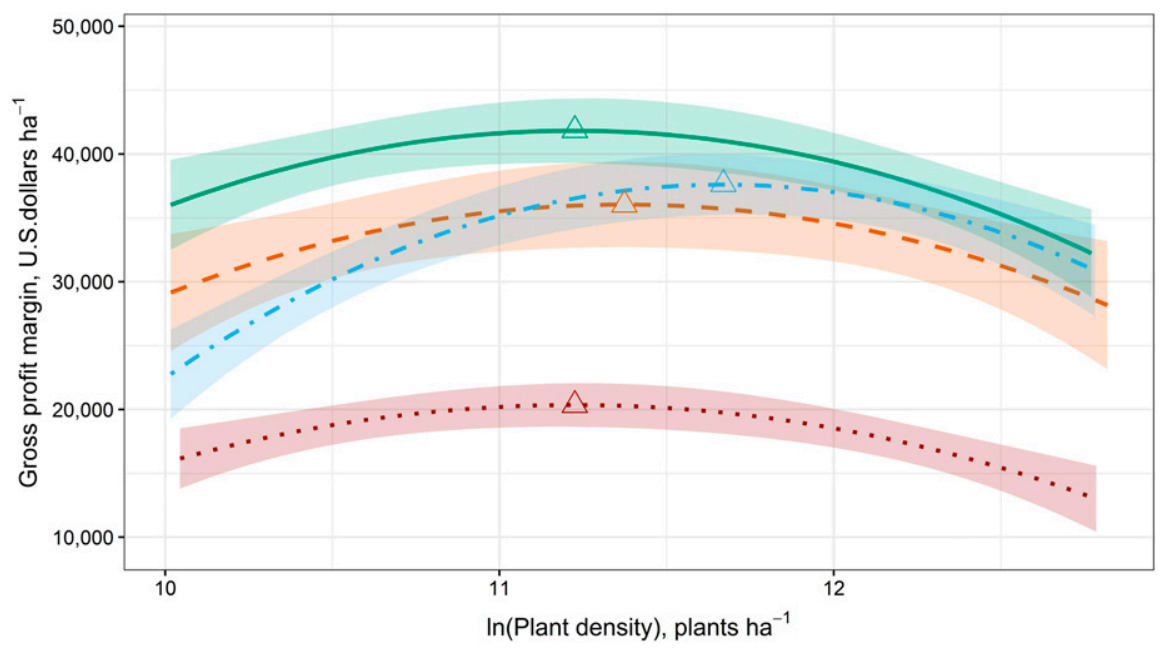

Fig. 3. Relationship between gross profit margin and plant density of four edamame cultivars. Gross profit margin estimates the total pod yield returns to growers after accounting for seed cost. EOPD that maximizes gross profit margin is indicated by a triangle symbol for each cultivar. Ninety-five percent confidence intervals are shown by the shaded regions around the line of best fit.

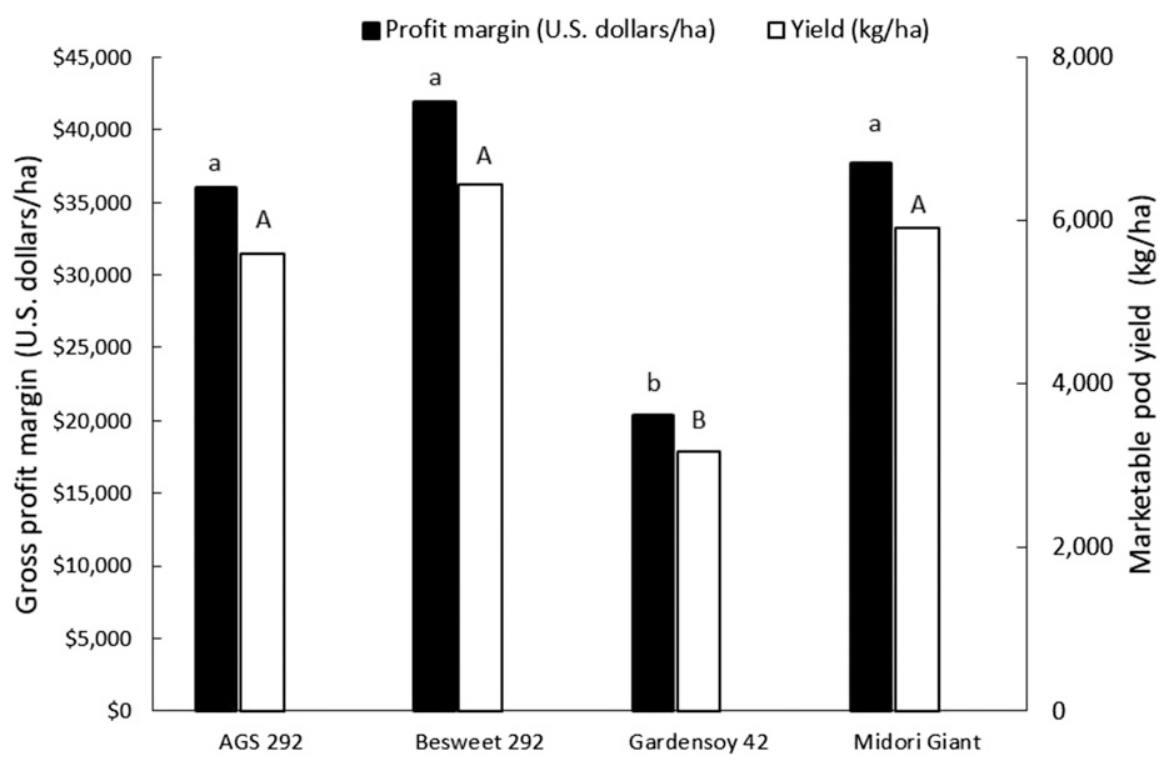

Fig. 4. Maximum gross profit margin and marketable pod yield at economically optimal plant densities for four edamame cultivars. Denoted by lowercase letters (maximum profit margin) and uppercase letters (marketable pod yield), cultivars with the same letter are not significantly different based on nonoverlapping $95 \%$ confidence intervals.

greater than 'Gardensoy 42' (Fig. 4). The EOPD was 87,000 plants/ha, 94,000 plants/ha, 106,000 plants/ha, and 120,000 plants/ha for 'Besweet 292', 'Gardensoy 42', 'AGS 292', and 'Midori Giant', respectively (Fig. 3).

\section{Discussion}

This study was conducted to evaluate plant morphological and yield responses to plant density among commercially available edamame cultivars. Given the paucity of data and literature in this area of research, coupled with increased domestic production of edamame, particular emphasis was placed on determining the EOPD of the crop. and Hume, 1978). Previous studies have reported that grain-type soybean cultivars are able to modify main stem branches under different plant densities, also known as branching plasticity (Agudamu and Shiraiwa, 2016; Board, 2000). Plants bear more branches at sparse plant densities compared with crowded conditions. Our findings in this study corroborate similar relationships to grain-type soybean in plant height and number of main stem branches with plant density in edamame.

Edamame plants under crowding stress bear fewer pods and produce more vegetative biomass. A recent study from Brazil reported average pod number per plant in grain-type soybean decreased from 67.6 to 27.9 as plant density increased from 150,000 to 450,000 plants/ha (Umburanas et al., 2019). Similarly, Cox and Cherney (2011) reported $27 \%$ fewer pods per plant at 469,000 compared with 321,000 plants/ha in grain-type soybean. Lower pod yield at higher plant densities is mainly associated with reduced number of main stem branches observed at such densities. In grain-type soybean, alterations in the branch reproductive node per plant determine the branch pod per plant (Carpenter and Board, 1997). Board et al. (1999) documented that increased pods per plant, primarily due to increased branching, is the secondary yield component most responsible for grain-type soybean yield compensation to increased space either within or between rows. Fewer pods per plant at high plant density not only reduce total pod yield, but also increase overall vegetative biomass, potentially interfering with machine harvest and exacerbating losses in pod yield.

Plant architecture influences the efficiency of machine harvest of edamame. Reduced branching at higher plant densities is associated with taller plants $(r=-0.41)$ and increased LAI $(r=-0.42)$, which interfere with Oxbo harvest efficiency of edamame. Edamame plant height in the range of 55 to $60 \mathrm{~cm}$ is considered ideal for mechanical harvest using a common bean picker (Mebrahtu and Mullins, 2007). Meanwhile, excessive plant biomass can cause machine plugging and reduce harvest efficiency (Zandonadi et al., 2010). Li et al. (2013) found a negative correlation $(r=-0.36)$ between edamame plant height and pod yield, and therefore recommended development of semidwarf cultivars in edamame breeding programs. In the present work, plant height was negatively correlated to pod yield per plant $(r=-0.43)$ and mechanical harvest efficiency $(r=-0.59)$. Likewise, fresh plant biomass and mechanical harvest efficiency showed a negative correlation $(r=-0.75)$. Because commercial edamame production in North America is viable with mechanized harvest, development of future cultivars must consider plant architecture characteristics that favor efficiency of machine harvest.

Contrary to grain-type soybean yields that reach an asymptote at the highest plant densities (Duncan, 1986; Edwards and Purcell, 2005; Egli, 1988), edamame pod yield reveals a quadratic response to plant density. Specifically, studies have shown that graintype soybean yields plateau at plant densities above 250,000 plants/ha (Nafziger, 2009). The 
discrepancy in yield response between edamame and grain-type soybean can be attributed in part to different developmental stages at the time of harvest for the two crops. Graintype soybean is harvested at full maturity (R8 stage; Fehr et al., 1971) when plants have senesced and optimum seed moisture between $13 \%$ and $15 \%$. In contrast, edamame cultivars are harvested before plant senescence, when seeds are immature and have a moisture between $65 \%$ to $70 \%$. Moreover, undersized seeds of edamame are nonmarketable. Fresh plant biomass of edamame at harvest, which increases with plant density, can interfere with mechanical harvest, reducing harvest efficiency and machine-harvested pod yield.

There is a confluence of economic, biological, and mechanical factors that influence the relationship between edamame plant density and EOPD. Seeding cost increases with plant density. From a biological standpoint, higher plant densities for edamame are associated with increase in LAI and plant height, which adds greater volume of vegetative biomass, resulting in reduced Oxbo harvest efficiency, and hence lower machine-harvested pod yields. Collectively, these interlinked economic, biological, and mechanical factors curtail EOPDs in edamame.

Current edamame seeding rate recommendations are similar to grain-type soybean Edamame EOPDs identified in this study are much lower than such recommendations. Specifically, current edamame planting recommendations up to 344,200 plants/ha are 2.9 to 4.0 times greater than EOPDs identified in this study. The EOPDs identified in this work account for the confluence of economic, biological, and mechanical factors that influence marketable pod yield and profitability. To our knowledge, this research provides the most comprehensive research and analysis to date for guiding decisions on plant density in commercial edamame production.

\section{Literature Cited}

Agudamu, T.Y. and T. Shiraiwa. 2016. Branch development responses to planting density and yield stability in soybean cultivars. Plant Prod. Sci. 19:331-339.

Barlow, Z. 2018. Soy-edamame: 70\% imported from China-U.S. researchers working on U.S. bean. Virginia Tech University. 1 Nov. 2018. $<$ https://agfax.com/2018/11/01/soy-edamame70-imported-from-china-u-s-researchers-workingon-u-s-bean/s.

Board, J.E. 2000. Light interception efficiency and light quality affect yield compensation of soybean at low plant populations. Crop Sci. 40:1285-1294.

Board, J.E. and C.S. Kahlon. 2013. Morphological responses to low plant population differ between soybean genotypes. Crop Sci. 53:1109-1119.

Board, J.E., M.S. Kang, and B.G. Harville. 1999. Path analyses of the yield formation process for late-planted soybean. Agron. J. 91:128-135.

Carpenter, A.C. and J.E. Board. 1997. Branch yield components controlling soybean yield stability across plant populations. Crop Sci. 37:885-891.

Cox, W. and J.H. Cherney. 2011. Growth and yield responses of soybean to row spacing and seeding rate. Agron. J. 103:123-128.
Crawford, L.E. and M.M. Williams, II. 2018. Role of edamame (Glycine max) seed size in earlyseason crop-weed interactions. Weed Sci. 66:746-751.

Crawford, L.E. and M.M. Williams, II. 2019. Planting depth and seed size affect edamame emergence individually. HortScience 54:9294.

Crawford, L.E., M.M. Williams, II, and S.E. Wortman. 2018. An early-killed rye (Secale cereale) cover crop has potential for weed management in edamame (Glycine max). Weed Sci. 66:502507.

Dominguez, C. and D.J. Hume. 1978. Flowering, abortion, and yield of early-maturing soybeans at three densities. Agron. J. 70:801-805.

Duncan, W.G. 1986. Planting patterns and soybean yields. Crop Sci. 26:584-588.

Duppong, L.M. and H. Hatterman-Valenti. 2005. Yield and quality of vegetable soybean cultivars for production in North Dakota. HortTechnology 15:896-900

Edwards, J.T. and L.C. Purcell. 2005. Soybean yield and biomass responses to increasing plant population among diverse maturity groups. Crop Sci. 45:1770-1777.

Egli, D.B. 1988. Plant density and soybean yield. Crop Sci. 28:977-981.

Fedco Seeds. 2019. 8 Mar. 2019. <https://www fedcoseeds.com/seeds/list-edamame $>$.

Fehr, W.R., C.E. Caviness, D.T. Burmood, and J.S. Pennington. 1971. Stage of development descriptions for soybeans, Glycine $\max (\mathrm{L}$.) Merrill. Crop Sci. 11:929-931.

Johnny's Selected Seeds. 2019. 8 Mar. 2019. <https:// www.johnnyseeds.com/vegetables/beans/ soybeans/>.

Hunsberger, L., J. Simon, W.J. Sciarappa, D. Shen, Q.L. Wu, and B. Hulme. 2007. Evaluation of edamame cultivars in New Jersey and Maryland. $<$ https://ssrn.com/abstract=2032208>.

Illinois Climate Network. 2019. Illinois climate network: monthly and daily data. 24 June 2019. $<$ https://www.isws.illinois.edu/warm/datatype. asp $>$.

Karlen, D.L., K. Delate, R. Turnbull, and J. Boes. 2004. Organic soybean production: Challenges and perspectives of an increasing trend. Proc. VII World Soybean Research Conf., VI International Soybean Processing and Utilization Conference, and III Congresso Brasileiro de Soja. 29:319-327.

Lehman, W.F. and J.W. Lambert. 1960. Effects of spacing of soybean plants between and within rows on yield and its components. Agron. J. 52:84-86

Li, Y.S., M. Du, Q.Y. Zhang, M. Hashemi, X.B. Liu, and S.J. Hebert. 2013. Correlation and path coefficient analysis for yield components of vegetable soybean in Northeast China. Legume Res. 36:284-288.

Matsuo, N., T. Yamada, Y. Takada, K. Fukami, and M. Hajika. 2018. Effect of plant density on growth and yield of new soybean genotypes grown under early planting condition in southwestern Japan. Plant Prod. Sci. 21:1625 .

Mebrahtu, T. and C. Mullins. 2007. Efficiency of mechanical harvest for immature vegetable soybean pods. Va. J. Sci. 58:165-174.

Mehmet, O.Z. 2008. Nitrogen rate and plan population effects on yield and yield components in soybean. Afr. J. Biotechnol. 7:4464 4470.

Miles, C.A., T.A. Lumpkin, and L. Zenz. 2000. Edamame. Food \& farm connection. Wash
State Univ. Coop. Ext. Pacific Northwest Ext. Publ. PNW0525.

Nafziger, E. 2009. Soybean. Illinois Agronomy Handbook. 24th ed. Champaign, IL: University of Illinois Extension. 2009:27-36.

Oh, Y.J., K.H. Kim, S.K. Suh, S.D. Kim, H.K Park, J.H. Ryu, J.G. Kim, A.J. Wood, and Y. Cho. 2007. Effects of stem lengths on seed yield and yield components of late planted soybeans. World J. Agric. Sci. 3:363-370.

Pedersen, P. and J.G. Lauer. 2003. Corn and soybean response to rotation sequence, row spacing, and tillage system. Agron. J. 95:965-971.

Rao, M.S.S., A.S. Bhagsari, and A.I. Mohamed 2002. Fresh green seed yield and seed nutritional traits of vegetable soybean genotypes. Crop Sci. 42:1950-1958.

Shanmugasundaram, S., S.T. Cheng, M.T. Huang, and M.R. Yan. 1991. Varietal improvement of vegetable soybean in Taiwan, p. 30-42. In: S. Shanmugasundaram (ed.). Vegetable soybean: Research needs for production and quality improvement. Asian Vegetable Research and Development Center, Taiwan.

Shanmugasundaram, S. and M.R. Yan. 2004 Global expansion of high value vegetable soybean. Proc. VII World Soybean Conf./IV Intl. Soybean Processing and Utilization Conf./III Brazilian Soybean Congr., Foz do Iguassu, Brazil, 29 Feb.-5 Mar. 2004.

Umburanas, R.C., A.H. Yokoyama, L. Balena, D Dourado-Neto, W.F. Teixeira, R.K. Zito, K Reichardt, and J. Kawakami. 2019. Soybean yield in different sowing dates and seeding rates in a subtropical environment. Intl. J. Plant Prod. 13:117-128.

U.S. Department of Agriculture, National Agricultural Statistics Service (USDA-NASS). 2019. Crops and plant statistics. 19 June 2019. $<$ https://www.nass.usda.gov/Statistics_by_ Subject/index.php? sector $=$ CROPS $>$.

U.S. Department of Agriculture, Economic Research Service (USDA-ERS). 2019. Commodity costs and returns. 25 Sept. 2019. <ers.usda.gov/ data-products/commodity-costs-and-returns/>.

Wannamaker Seeds. 2019. 8 Mar. 2019. <http:// www.wannamakerseeds.com/order.html>.

Wilcox, J.R. and T. Sediyama. 1981. Interrelationships among height, lodging and yield in determinate and indeterminate soybeans. Euphytica 30:323-326

Williams, M.M., II, N.E. Hausman, and J.L. Moody. 2017. Vegetable soybean tolerance to pyroxasulfone. Weed Technol. 31:416420 .

Williams, M.M., II, J.L. Moody, and N.E. Hausman. 2019. Vegetable soybean tolerance to flumioxazinbased treatments for waterhemp control is similar to grain-type soybean. Weed Technol. 33:530534

Williams, M.M., II, and R.L. Nelson. 2014. Vegetable soybean tolerance to bentazon, fomesafen, imazamox, linuron, and sulfentrazone. Weed Technol. 28:601-607.

Zandonadi, R., T. Stombaugh, T. Coolong, and T. Pfeiffer. 2010. Mechanical harvesting of edamame. 14 July 2017. <http://www.uky.edu/Ag/ ccd/edamameharvest.pdf $>$.

Zhang, L. and S. Kyei-Boahen. 2007. Growth and yield of vegetable soybean (Edamame) in Mississippi. HortTechnology 17:26-31.

Zhang, Q.Y., M. Hashemi, S.J. Hebert, and Y.S. Li. 2013. Different responses of preemergence and early seedling growth to planting depth between vegetable soybean and grain soybeans. Legume Res. 36:515-521. 